\title{
Developing a BIM-based process-driven decision-making framework for sustainable building envelope design in the tropics
}

\author{
Y.-W. Lim ${ }^{1}$, F. Shahsavari ${ }^{1}$, N. Fazlenawati ${ }^{1}$, M. N. Azli ${ }^{1}$, \\ D. R. Ossen ${ }^{1} \&$ M. H. Ahmad ${ }^{2}$ \\ ${ }^{1}$ Department of Architecture, Faculty of Built Environment, \\ Universiti Teknologi Malaysia, Malaysia \\ ${ }^{2}$ Institute Sultan Iskandar, Universiti Teknologi Malaysia, Malaysia
}

\begin{abstract}
There is a rising concern for sustainability in the built environment. Therefore, numerous sustainable building certification and rating systems are developed throughout the world. However, the current methods of measuring, predicting, and optimising the sustainable building design have relied on a number of disjointed analyses to meet the discrete requirements for various building systems. The recent development of Building Information Modelling (BIM) technology allows complicated building modelling to be digitally constructed with precise geometry and accurate information to support various building project stages. Thereby, this study aims to integrate decision-making (DM) for sustainable building envelope design with BIM functionalities by considering the tropical climatic contexts in Malaysia. Several regional sustainable building certification systems and related literature were reviewed to identify the importance of evaluation and DM criteria. The findings were then compared with various BIM tools in terms of their applications, functions and workflows, in order to formulate a process-driven BIM-based DM framework (DMF) for sustainable building design in Malaysia. The proposed DMF will address the difficulties of DM in the early design development process, and will also allow for specific trade-off analyses of sustainability and objective-based optimisation using BIM.

Keywords: GreenBIM, design process, AEC industry, sustainable architecture, tropical.
\end{abstract}




\section{Introduction}

In the past 20 years, numerous certification and rating systems are available throughout the world for sustainable building, including LEED in US; BREEAM in UK; Green Mark in Singapore; and Green Star in Australia. Each of these systems requires different types of performance goals to evaluate and to benchmark the levels of green building revolution. Green Building Index (GBI) [1] and GreenRE [2] have been introduced to Malaysia in 2009 and 2013 respectively, both are sustainable building rating systems for non-residential new construction, residential new construction, and existing non-residential buildings. Some of the criteria in GBI and GreenRE actually used the benchmarks as stated in MS 1525 [3] such as overall thermal transfer value (OTTV) and roof thermal transfer value (RTTV).

The term 'sustainability' comprises a wide range of components: environmental quality, society well-being, and economic stability. These components often lead to conflict; therefore, it is very difficult to integrate these components into a single green rating [4]. However, the current design decisionmaking (DM) for sustainable buildings much depends on a number of disjointed analyses, to determine whether discrete requirements are best met with various building systems (e.g. HVAC, plumbing, lighting) or design features (e.g. landscaping, renewable energy generation, parking). Although many studies have pointed that the best opportunities for building sustainability improvement occurred in the early design or pre-construction stages, in the conventional architecture, engineering and construction (AEC) practice, surveys had found that the design DM for building sustainability occurred in the later stages $[5,6]$.

With the development of Building Information Modelling (BIM) technology, complex building modelling can be digitally constructed with both precise geometry and accurate information in order to support various project stages. Many researchers had stated the benefits of BIM in AEC industry such as accurate data environment, effective design process, accurate project cost estimation, time saving, and other benefits [7-11]. The additional functionality of BIM parametric modelling also allows conduct various analyses for design DM.

The applications of BIM for sustainable building design or GreenBIM model had been investigated widely recently. For instance, the data of BIM model can be utilised for green rating evaluation [12, 13]. BIM-based model can also be used for post-occupancy evaluation process [14, 15] and waste reduction of renovation projects [16]. Bank et al. [4] investigated the possibility of developing a decision-making (DM) framework for sustainable building design and operation by integrating BIM with System Dynamics. Kim et al. [13] aimed to develop Green BIM Template (GBT) for Green Building Certification Criteria $(\mathrm{GBCC})$ in South Korea.

From the recent development on BIM-based sustainability or GreenBIM, it shows the importance of extracting data from BIM for sustainable building design DM. Hence, a decision-making framework (DMF) is needed to understand the extent and benefits of applying BIM in early stages of building 
design. A BIM-based DMF can give the designers a well-defined workflow to support the DM process using BIM based on regional sustainable building certification systems. Thereby, this study aims to integrate DM which comprises sustainable building envelope design and BIM functionalities with the consideration on the tropical climatic contexts in Malaysia. This study focuses on the early design or pre-construction stages which includes conceptual and schematic design as well as design development stages.

\section{Methodology}

Design DM for sustainable building envelope design is multifaceted; it requires energy consumption, PMV, daylighting, initial cost, and other aspects. DM is affected by many design variables such as window position, window-to-wall ratio, shading device geometry, type of glazing, wall material and so on. Therefore, DM for architectural optimal sustainable design involves searching for a multi-criteria optimal design solution set based on various sustainability indicators $[4,17,18]$. In this study, a BIM-based DMF for sustainable building envelope design was developed after considering certain aspects such as design process, sustainability indicators and functionality of BIM tools. Several regional sustainable building certification systems and related literature were reviewed to identify the importance of process and evaluation criteria for sustainable DM building envelope design. DM process and criteria then were compared and matched with BIM functionality and Level of Development (LOD). The finding of the study has established an objective-based process-driven DM framework (DMF) for sustainable building envelope design.

\section{Development of BIM-based decision-making framework}

\subsection{Definition of sustainable design decision-making criteria}

The review of several regional sustainable building certification systems and literature has highlighted the different DM criteria for sustainable building envelope design. All the criteria were then categorised according the different design variables: 1. Opening position, 2. Opening size, 3. Shading device, 4. Window glazing type, 5. Wall type and material, 6. Roof geometry, 7. Roof opening geometry, 8. Skylight geometry, 9. Skylight glazing, 10. Roof type and material. Different design variables require different sustainable design DM criteria by responding to the local climate. For instance, the position of window openings shall avoid facing east-west orientations in order to minimise direct solar heat gain; whereas the construction of building façade and roof shall maximise the use of regional and sustainable materials. The DM criteria and related references based on the various building envelope design variables are summarised in Table 1. 
Table 1: Summary of sustainable building envelope design DM criteria.

\begin{tabular}{|c|c|c|}
\hline $\begin{array}{l}\text { Design } \\
\text { variable }\end{array}$ & Sustainable design DM criteria & References \\
\hline $\begin{array}{l}\text { V1- } \\
\text { Opening } \\
\text { position }\end{array}$ & $\begin{array}{l}\text { - Minimise east-west facing opening to avoid direct sunlight } \\
\text { - Maximise north-south facing opening to capture prevailing wind } \\
\text { - Maximise north-south facing opening to receive sufficient } \\
\text { - } \text { daylight } \\
\text { - Provide good distribution of daylight }\end{array}$ & {$[2,19-22]$} \\
\hline $\begin{array}{l}\text { V2- } \\
\text { Opening size }\end{array}$ & $\begin{array}{l}\text { - Minimise heat gain } \\
\text { - Assure each space has sufficient operable opening area (WFR) } \\
\text { for ventilation } \\
\text { - Provide sufficient indoor air movement and air change } \\
\text { - Provide sufficient indoor illuminance } \\
\text { - Minimise daylight glare }\end{array}$ & $\begin{array}{c}{[1,2,19,20,} \\
22-31]\end{array}$ \\
\hline $\begin{array}{l}\text { V3- } \\
\text { Shading } \\
\text { device }\end{array}$ & $\begin{array}{l}\text { - Use of solar shading to shade east-west facing opening } \\
\text { - Optimise shading geometry } \\
\text { - Minimise OTTV } / \text { RETV }^{2} \\
\text { - Minimise heat gain } \\
\text { - Use of shading device to control daylight quantity and quality } \\
\text { - Minimise daylight glare } \\
\text { - Use of PV as shading device }\end{array}$ & $\begin{array}{c}{[1-3,19-21,} \\
24,26,31-45]\end{array}$ \\
\hline $\begin{array}{l}\text { V4- } \\
\text { Window } \\
\text { glazing type }\end{array}$ & $\begin{array}{l}\text { - } \text { Minimise } \mathrm{OTTV}^{1} / \mathrm{RETV}^{2} \\
\text { - Minimise heat gain } \\
\text { - Provide sufficient indoor illuminance } \\
\text { - } \text { Minimise daylight glare }\end{array}$ & $\begin{array}{l}{[1-3,21,24} \\
26,28,31,33 \\
34,41,45-53]\end{array}$ \\
\hline $\begin{array}{l}\text { V5- } \\
\text { Wall type } \\
\text { and material }\end{array}$ & $\begin{array}{l}\text { - Minimise OTTV }{ }^{1} / \mathrm{RETV}^{2} \\
\text { - Minimise heat gain } \\
\text { - Use of green wall to reduce heat gain } \\
\text { - Use of regional building material } \\
\text { - Use of sustainable building material } \\
\end{array}$ & $\begin{array}{c}{[1-3,28,30} \\
41,47,49,50 \\
51,53-56]\end{array}$ \\
\hline $\begin{array}{l}\text { V6- } \\
\text { Roof } \\
\text { geometry }\end{array}$ & $\begin{array}{l}\text { - Use of roof overhang to shade east-west facing façade } \\
\text { - Use of pitch angle to reduce incident solar heat gain (solar } \\
\text { factor) } \\
\text { - Optimise roof area for PV }\end{array}$ & $\begin{array}{c}{[1-3,47,50} \\
57]\end{array}$ \\
\hline \begin{tabular}{l|} 
V7- \\
Roof opening \\
geometry
\end{tabular} & $\begin{array}{l}\text { - Use of roof opening or solar chimney for stack ventilation } \\
\text { - Provide sufficient indoor air movement and air change }\end{array}$ & {$[58,59]$} \\
\hline $\begin{array}{l}\text { V8- } \\
\text { Skylight } \\
\text { geometry }\end{array}$ & $\begin{array}{l}\text { - Shade the skylight from direct sunlight } \\
\text { - Orientate the skylight to face north-south orientations } \\
\text { - Provide sufficient indoor illuminance } \\
\text { - Provide good distribution of daylight }\end{array}$ & {$[52,60,61]$} \\
\hline $\begin{array}{l}\text { V9- } \\
\text { Skylight } \\
\text { glazing }\end{array}$ & $\begin{array}{l}\text { - Minimise RTTV } \\
\text { - Minimise heat gain } \\
\text { - Provide sufficient indoor illuminance }\end{array}$ & $\begin{array}{c}{[1-3,49,52,} \\
62-65]\end{array}$ \\
\hline $\begin{array}{l}\text { V10- } \\
\text { Roof type } \\
\text { and material }\end{array}$ & $\begin{array}{l}\text { - Use of thermal insulation to reduce heat gain } \\
\text { - Minimise } \mathrm{RTTV}^{3} \\
\text { - Minimise heat gain } \\
\text { - Use of regional building material } \\
\text { - Use of sustainable building material } \\
\text { - Use of green roof for cooling }\end{array}$ & {$[1-3,41,51]$} \\
\hline
\end{tabular}

$\mathrm{OTTV}^{1}=$ applicable for buildings with AC area $>1000 \mathrm{~m}^{2}$

$\mathrm{RETV}^{2}=$ applicable for residential building

$\mathrm{RTTV}^{3}=$ applicable for roof with skylight 


\subsection{Comparison of decision-making with Level of Development}

Level of Development (LOD) in BIM had been defined by various previous studies in order to standardise the precision and suitability of a BIM for specific uses. LOD describes the steps of a BIM element to progress logically from the lowest level of conceptual approximation to the highest level of representational precision, which allows practitioners in AEC industry to articulate the content of a BIM at various project stages (Bedrick [66], BIMForum [67], Wood et al. [68]). In general, the LOD are defined as: 100 for conceptual design; 200 for schematic design with approximate geometry; 300 for developed design with precise geometry; 350 for tender and coordination; 400 for construction and fabrication; and 500 for as-built.

A BIM-based sustainable building envelope design DM needs to be processdriven according to BIM workflow. Therefore, the sustainable building envelope design DM process was defined by comparing the design variables with the BIM LOD. This study only focuses on conceptual or schematic design and design development stage of a project, thus LOD 100, 200 and 300 can only be selected for the comparison. The match-up of the design process with the selected BIM LOD is presented in Table 2.

Table 2: $\quad$ Match up of design process with BIM LOD 100 to LOD 300.

\begin{tabular}{|c|l|c|}
\hline LOD & Model content requirement [66-68] & Design variable \\
\hline 100 & $\begin{array}{l}\text { Non-geometric data, symbol or line work, area, } \\
\text { height, volume, zone, location, orientation or } \\
\text { other generic representation. }\end{array}$ & V1, V6, V7 \\
\hline 200 & $\begin{array}{l}\text { Generic elements or assembly shown in three } \\
\text { dimensions, with approximate quantities, size, } \\
\text { shape, location, and orientation. Non-graphic } \\
\text { information may also be attached to the } \\
\text { elements. }\end{array}$ & V2, V3, V8 \\
\hline 300 & $\begin{array}{l}\text { Specific system, object or assembly in terms of } \\
\text { quantity, size, shape, location, and orientation. } \\
\text { Non-graphic information may also be attached } \\
\text { to the elements. }\end{array}$ & V4, V5, V9, V10 \\
\hline
\end{tabular}

\subsection{Formulation of BIM-based process-driven DMF}

Based on the sustainable building envelope design DM criteria and the match-up with BIM LOD, a BIM-based process-driven DM framework (DMF) for sustainable building envelope design was formulated. Table 3 represents the BIM-based DMF for building façade and roof design according to schematic or conceptual design (LOD 100 and 200) and design development (LOD 300) stages.

Objective functions were determined for every design variables based on the DM criteria as defined in Table 1. For instance, to minimise the percentage of east-west facing window areas over total east-west facing façade areas is one of 
Table 3: Integrated BIM and objective-based process-driven decision-making framework for sustainable building envelope design in Malaysia.

\begin{tabular}{|c|c|c|c|c|c|c|c|c|c|c|}
\hline \multirow{3}{*}{$\begin{array}{l}\text { Design } \\
\text { Element } \\
\text { Category }\end{array}$} & \multicolumn{10}{|c|}{ Project Stage } \\
\hline & \multicolumn{5}{|c|}{ Schematic / Conceptual Design [LOD 100, 200] } & \multicolumn{5}{|c|}{ Design Development [LOD 300] } \\
\hline & \begin{tabular}{c|} 
Design \\
Variable
\end{tabular} & Strategy & Objective Function & $\begin{array}{c}\text { Decision- } \\
\text { making }\end{array}$ & Tool & $\begin{array}{c}\text { Design } \\
\text { Variable }\end{array}$ & Strategy & Objective Function & $\begin{array}{c}\text { Decision- } \\
\text { making }\end{array}$ & Tool \\
\hline \multirow{15}{*}{ Façade } & $\begin{array}{c}\text { Window size } \\
\text { [WWR] }\end{array}$ & \multirow{3}{*}{$\begin{array}{l}\text { Solar } \\
\text { Shading }\end{array}$} & $\begin{array}{l}\text { \% of E-W facing window areas } \\
\text { over total E-W facing façade } \\
\text { areas }\end{array}$ & \begin{tabular}{|l|} 
The lower \\
the better
\end{tabular} & Calculation & \begin{tabular}{|c|} 
Glazing \\
[VT, U-value, \\
SC]
\end{tabular} & \multirow{3}{*}{ Thermal } & $\begin{array}{l}\text { OTTV (applicable for building } \\
\text { with AC area }>1000 \mathrm{~m}^{2} \text { ) }\end{array}$ & $\leq 50 \mathrm{~W} / \mathrm{m}^{2}$ & Calculation \\
\hline & $\begin{array}{l}\text { Window } \\
\text { position }\end{array}$ & & $\left|\begin{array}{l}\% \text { of E-W facing window areas } \\
\text { with sunshading devices over } \\
\text { total E-W facing façade areas }\end{array}\right|$ & $\begin{array}{l}\text { The higher } \\
\text { the better }\end{array}$ & Calculation & \begin{tabular}{|c|} 
Wall \\
material \\
[U-value, \\
solar \\
absorptivity] \\
\end{tabular} & & $\begin{array}{l}\text { RETV (applicable for } \\
\text { residential building) }\end{array}$ & $\leq 25 \mathrm{~W} / \mathrm{m}^{2}$ & Calculation \\
\hline & $\begin{array}{l}\text { Shading } \\
\text { device } \\
\text { geometry }\end{array}$ & & SC of Shading Device & $\begin{array}{l}\text { The higher } \\
\text { the better }\end{array}$ & $\begin{array}{c}\text { Refer to } \\
\text { Guidelines }\end{array}$ & $\begin{array}{l}\text { Shading } \\
\text { Device SC }\end{array}$ & & $\begin{array}{l}\text { Building cooling load (if } \\
\text { applicable) }\end{array}$ & $\begin{array}{l}\text { The lower } \\
\text { the better }\end{array}$ & Calculation \\
\hline & \multirow[t]{12}{*}{ Type of Wall } & \multirow{4}{*}{$\begin{array}{c}\text { Natural } \\
\text { Ventilation }\end{array}$} & $\begin{array}{l}\% \text { of spaces with window } \\
\text { opening facing N-S directions } \\
\text { for cross ventilation }\end{array}$ & $\begin{array}{l}\text { The higher } \\
\text { the better }\end{array}$ & Calculation & & \multirow{4}{*}{$\begin{array}{c}\text { Natural } \\
\text { Ventilation }\end{array}$} & Indoor wind velocity & $0.5-1.0 \mathrm{~m} / \mathrm{s}$ & $\begin{array}{c}\text { CFD } \\
\text { Simulation }\end{array}$ \\
\hline & & & $\%$ of spaces with WFR $\geq 10 \%$ & $\begin{array}{l}\text { The higher } \\
\text { the better }\end{array}$ & Calculation & & & Indoor air change rate & $\begin{array}{c}0.35 \mathrm{ACH} \\
\text { and } \geq 7.5 \mathrm{~L} / \mathrm{S}\end{array}$ & \begin{tabular}{|c|} 
CFD \\
Simulation \\
\end{tabular} \\
\hline & & & & & & & & Indoor air temperature & $22.5-28.5^{\circ} \mathrm{C}$ & \begin{tabular}{|c|}
$\begin{array}{c}\text { Thermal } \\
\text { Simulation }\end{array}$ \\
\end{tabular} \\
\hline & & & & & & & & Predicted Mean Vote (PMV) & 0 & \begin{tabular}{|c|} 
CFD \\
Simulation \\
\end{tabular} \\
\hline & & \multirow{3}{*}{ Dayligting } & $\begin{array}{l}\text { \% of } \mathrm{N}-\mathrm{S} \text { facing window areas } \\
\text { over total } \mathrm{N}-\mathrm{S} \text { facing façade } \\
\text { areas }\end{array}$ & $\begin{array}{l}\text { The higher } \\
\text { the better }\end{array}$ & Calculation & & \multirow{3}{*}{ Dayligting } & $\begin{array}{l}\% \text { of the NLA with DF } 1.0- \\
3.5 \%\end{array}$ & $\begin{array}{l}\text { The higher } \\
\text { the better }\end{array}$ & $\begin{array}{c}\text { Daylight } \\
\text { Simulation }\end{array}$ \\
\hline & & & \begin{tabular}{|l|}
$\%$ of the use of light shelf over \\
other shading devices
\end{tabular} & $\begin{array}{l}\begin{array}{l}\text { The higher } \\
\text { the better }\end{array} \\
\end{array}$ & Calculation & & & \begin{tabular}{|l|}
$\begin{array}{l}\text { Daylight uniformity ratio } \\
\text { (min/avg) }\end{array}$ \\
\end{tabular} & $\geq 0.5$ & $\begin{array}{c}\text { Daylight } \\
\text { Simulation } \\
\end{array}$ \\
\hline & & & & & & & & Daylight Glare Index & $\begin{array}{l}\text { Refer to } \\
\text { Index }\end{array}$ & \begin{tabular}{|c|} 
Daylight \\
Simulation \\
\end{tabular} \\
\hline & & \multirow{5}{*}{ Other } & $\begin{array}{l}\text { \% of green wall area over } \\
\text { total wall area (if applicable) }\end{array}$ & $\begin{array}{l}\text { The higher } \\
\text { the better }\end{array}$ & Calculation & & \multirow{5}{*}{ Other } & Building Energy Index (BEI) & $\begin{array}{l}\text { The lower } \\
\text { the better }\end{array}$ & \begin{tabular}{|c|} 
Energy \\
Simulation \\
\end{tabular} \\
\hline & & & $\begin{array}{l}\% \text { of solar shading device area } \\
\text { optimsed for PV (if applicable) }\end{array} \mid$ & $\begin{array}{l}\text { The higher } \\
\text { the better }\end{array}$ & $\begin{array}{c}\text { Solar } \\
\text { Simulation }\end{array}$ & & & $\begin{array}{l}\text { Renewable Energy production } \\
\text { (PV; if applicable) }\end{array}$ & $\begin{array}{l}\text { The higher } \\
\text { the better }\end{array}$ & $\begin{array}{c}\text { Energy } \\
\text { Simulation }\end{array}$ \\
\hline & & & & & & & & \begin{tabular}{|l|}
$\%$ of regional building \\
materials over total project's \\
material (based on cost) \\
\end{tabular} & $\begin{array}{l}\text { The higher } \\
\text { the better }\end{array}$ & Calculation \\
\hline & & & & & & & & \begin{tabular}{|l|}
$\%$ of sustainable building \\
materials over total project's \\
material (based on cost)
\end{tabular} & $\begin{array}{l}\text { The higher } \\
\text { the better }\end{array}$ & Calculation \\
\hline & & & & & & & & Construction cost & $\begin{array}{l}\text { The lower } \\
\text { the better }\end{array}$ & Calculation \\
\hline \multirow{14}{*}{ Roof } & Roof type & \multirow{3}{*}{$\begin{array}{c}\text { Solar } \\
\text { Shading }\end{array}$} & $\begin{array}{l}\% \text { of E-W facing façade areas } \\
\text { shaded by roof over total E-W } \\
\text { facing façade areas }\end{array}$ & $\begin{array}{l}\text { The higher } \\
\text { the better }\end{array}$ & $\begin{array}{c}\text { Solar } \\
\text { Simulation }\end{array}$ & $\begin{array}{c}\text { Roof } \\
\text { material } \\
\text { [U-value] }\end{array}$ & \multirow{3}{*}{ Thermal } & $\begin{array}{l}\% \text { of roof area with } \mathrm{U} \text {-value } \leq \\
0.4 \mathrm{~W} / \mathrm{m}^{2} \mathrm{k} \text { (light weight) or } \leq \\
0.6 \mathrm{~W} / \mathrm{m}^{2} \mathrm{k} \text { (heavy weight) } \\
\text { over total roof area }\end{array}$ & $\begin{array}{l}\text { The higher } \\
\text { the better }\end{array}$ & Calculation \\
\hline & $\begin{array}{c}\text { Roof } \\
\text { geometry }\end{array}$ & & $\begin{array}{l}\% \text { of indirect (shaded) skylight } \\
\text { area over total skylight area } \\
\text { (if applicable) }\end{array}$ & $\begin{array}{l}\text { The higher } \\
\text { the better }\end{array}$ & Calculation & \begin{tabular}{|c|} 
Skylight \\
Glazing \\
[VT, U-value, \\
SC] \\
\end{tabular} & & $\begin{array}{l}\text { RTTV (applicable for roof with } \\
\text { skylight) }\end{array}$ & $\leq 25 \mathrm{~W} / \mathrm{m}^{2}$ & Calculation \\
\hline & $\begin{array}{l}\text { Opening } \\
\text { geometry }\end{array}$ & & Solar Factor (SF) of the roof & $\begin{array}{l}\text { The lower } \\
\text { the better }\end{array}$ & \begin{tabular}{|c|} 
Refer to \\
Guidelines \\
\end{tabular} & Roof SF & & \begin{tabular}{|l|} 
Building cooling load (if \\
applicable)
\end{tabular} & $\begin{array}{l}\text { The lower } \\
\text { the better }\end{array}$ & Calculation \\
\hline & $\begin{array}{l}\text { Skylight } \\
\text { geometry }\end{array}$ & \multirow{4}{*}{$\begin{array}{c}\text { Natural } \\
\text { Ventilation }\end{array}$} & \begin{tabular}{|}
$\%$ of spaces with roof opening \\
/ solar chimney for stack \\
ventilation (if applicable)
\end{tabular} & $\begin{array}{l}\text { The higher } \\
\text { the better }\end{array}$ & Calculation & & \multirow{4}{*}{$\begin{array}{c}\text { Natural } \\
\text { Ventilation }\end{array}$} & Indoor wind velocity & $0.5-1.0 \mathrm{~m} / \mathrm{s}$ & $\begin{array}{c}\text { CFD } \\
\text { Simulation }\end{array}$ \\
\hline & & & & & & & & Indoor air change rate & $\begin{array}{c}0.35 \mathrm{ACH} \\
\text { and } \geq 7.5 \mathrm{~L} / \mathrm{s}\end{array}$ & $\begin{array}{c}\text { CFD } \\
\text { Simulation } \\
\end{array}$ \\
\hline & & & & & & & & Indoor air temperature & $22.5-28.5^{\circ} \mathrm{C}$ & $\begin{array}{c}\text { Thermal } \\
\text { Simulation } \\
\end{array}$ \\
\hline & & & & & & & & Predicted Mean Vote (PMV) & 0 & \begin{tabular}{c|} 
CFD \\
Simulation \\
\end{tabular} \\
\hline & & \multirow{2}{*}{ Dayligting } & $\begin{array}{l}\% \text { of } \mathrm{N}-\mathrm{S} \text { facing skylight areas } \\
\text { over total skylight areas }\end{array}$ & $\begin{array}{l}\text { The higher } \\
\text { the better }\end{array}$ & Calculation & & \multirow{2}{*}{ Dayligting } & $\begin{array}{l}\% \text { of the NLA with DF } 1.0- \\
3.5 \%\end{array}$ & $\begin{array}{l}\text { The higher } \\
\text { the better }\end{array}$ & \begin{tabular}{|c|} 
Daylight \\
Simulation \\
\end{tabular} \\
\hline & & & & & & & & \begin{tabular}{|l|}
$\begin{array}{l}\text { Daylight uniformity ratio } \\
(\mathrm{min} / \mathrm{avg})\end{array}$ \\
\end{tabular} & $\geq 0.5$ & \begin{tabular}{|c|} 
Daylight \\
Simulation \\
\end{tabular} \\
\hline & & \multirow{5}{*}{ Other } & $\begin{array}{l}\begin{array}{l}\% \text { of green roof area over } \\
\text { total roof area (if applicable) }\end{array} \\
\end{array}$ & $\begin{array}{l}\text { The higher } \\
\text { the better }\end{array}$ & Calculation & & \multirow{5}{*}{ Other } & Building Energy Index (BEI) & $\begin{array}{l}\text { The lower } \\
\text { the better }\end{array}$ & \begin{tabular}{|c|} 
Energy \\
Simulation \\
\end{tabular} \\
\hline & & & $\begin{array}{l}\text { \% of roof area optimsed for } \\
\text { PV (if applicable) }\end{array}$ & $\begin{array}{l}\text { The higher } \\
\text { the better }\end{array}$ & Calculation & & & \begin{tabular}{|l|}
$\begin{array}{l}\text { Renewable Energy production } \\
\text { (PV; if applicable) }\end{array}$ \\
\end{tabular} & \begin{tabular}{|l|} 
The higher \\
the better \\
\end{tabular} & \begin{tabular}{|c|} 
Energy \\
Simulation \\
\end{tabular} \\
\hline & & & & & & & & \begin{tabular}{|l|}
$\%$ of regional building \\
materials over total project's \\
material (based on cost) \\
\end{tabular} & $\begin{array}{l}\text { The higher } \\
\text { the better }\end{array}$ & Calculation \\
\hline & & & & & & & & \begin{tabular}{|l|}
$\%$ of sustainable building \\
materials over total project's \\
material (based on cost)
\end{tabular} & $\begin{array}{l}\text { The higher } \\
\text { the better }\end{array}$ & Calculation \\
\hline & & & & & & & & Construction cost & $\begin{array}{l}\text { The lower } \\
\text { the better }\end{array}$ & Calculation \\
\hline
\end{tabular}


the objective functions to avoid direct solar radiation heat gain in the tropics. Besides, related BIM functionalities or tools for every DM were determined based on the review of various BIM software such as Autodesk Revit, Integrated Environmental Solutions $<$ Virtual Environment $>$ (IES $<$ VE $>$ ), Autodesk Ecotect Analysis, Design Builder and so on.

\section{Conclusion}

This study integrates DM for sustainable building envelope design and BIM functionalities with special reference to the tropical climatic contexts in Malaysia. Several regional sustainable building certification systems and related literature were reviewed to determine the importance of DM criteria. The objective-based DMF was defined based on BIM LOD and relevant BIM functionalities. It addresses the difficulties of DM in early design process, and allows for specific sustainability trade-off analyses and optimisation to be conducted using BIM. This study can be further developed as a BIM-based DM and optimisation tool.

\section{Acknowledgement}

The authors would like to acknowledge the research funding by Ministry of Education Malaysia (MOE) through Fundamental Research Grant Scheme (FRGS) Vote 4F665, titled "BIM-GBI Model Development: Integrating Building Information Modelling and Green Building Certification in Malaysia”.

\section{References}

[1] Green Building Index (GBI). Design Reference Guide (1st ed.), Green Building Index Sdn. Bhd.: Kuala Lumpur, Malaysia, 2009.

[2] GreenRE. Design Reference Guide (Version 1.1), GreenRE: Kuala Lumpur, Malaysia, 2013.

[3] MS 1525. Malaysian Standard, Code of Practice on Energy efficiency and Use of Renewable Energy for Non-Residential Buildings (2nd Revision), Department of Standards Malaysia: 2014.

[4] Bank, L.C., McCarthy, M., Thompson, B.P., \& Menassa, C.C., Integrating BIM with System Dynamics as a Decision-Making Framework for Sustainable Building Design and Operation. Proc. of the $1^{\text {st }}$ Int. Conf. On Sustainable Urbanization (ICSU 2010), Hong Kong, China, pp. 15-17, 2010.

[5] Schlueter, A. \& Thesseling, F., Building information model based energy/exergy performance assessment in early design stages. Automation in Construction, 18, pp. 153-163, 2009.

[6] Azhar, S \& Brown, J., BIM for Sustainability Analyses. International Journal of Construction Education and Research, 5(4), pp. 276-292, 2009. 
[7] Azhar, S., Nadeem, A., Mok, J.Y.N. \& Leung, B.H.Y., Building Information Modeling (BIM): A New Paradigm for Visual Interactive Modeling and Simulation for Construction Projects. Proc. of the $1^{\text {st }}$ Int. Conf. On Construction in Developing Countries, Karachi, Pakistan, pp. 435-446, 2008.

[8] Gu, N. \& London, K., Understanding and facilitating BIM adoption in the AEC industry. Automation in Construction, 19, pp. 988-999, 2010.

[9] Sanguinrtti, P., Abdelmohsen, S., Lee, J., Lee, J., Sheward, H. \& Eastman, C., General system architecture for BIM: An integrated approach for design and analysis. Advanced Engineering Informatics, 26, pp. 317-333, 2012.

[10] Barlish, K. \& Sullivan, K., How to measure the benefits of BIM - A case study approach. Automation in Construction, 24, pp. 149-159, 2012.

[11] Bryde, D., Broquetas, M. \& Volm, J.M., The project benefits of Building Information Modelling (BIM). International Journal of Project Management, 31(7), pp. 971-980, 2013.

[12] Azhar, S., Carlton, W.A., Olsen, D., \& Ahmad I., Building information modeling for sustainable design and LEED ${ }^{\circledR}$ rating analysis. Automation in Construction, 20(2), pp. 217-224, 2011.

[13] Kim, I., Kim, M. \& Jun, H., GBT for BIM-based Green Building Certification System. Proc. Of Int. Conf. On Sustainable Building Asia (SB13), Seoul, South Korea, pp. 193-197, 2013.

[14] Motawa, I. \& Carter, K., Sustainable BIM-based Evaluation of Buildings. Procedia Social and Behavioural Sciences, 74, pp. 116-125, 2013.

[15] Lee, S.W. \& Tae, S.H., The Analysis of BIM Modeling Level Considered as Building Greenhouse Gases Assessment. Proc. Of Int. Conf. On Sustainable Building Asia (SB13), Seoul, South Korea, pp. 209-215, 2013.

[16] Cheng, J.C.P. \& Ma, L.Y.H., A BIM-based system for demolition and renovation waste estimation and planning. Waste Management, 33, pp. 1539-1551, 2013.

[17] Wang, W., Zmeureanu, R. \& Rivard, H., Applying multi-objective genetic in green building design optimization. Building and Environment, 40(11), pp. 1512-1525, 2005.

[18] Hopfe, C.J., Uncertainty and sensitivity analysis in building performance simulation for design for decision support and design optimization. Ph.D. thesis, Technische Universiteit Eindhoven, Netherlands, 2009.

[19] Liping, W. \& Hien, W.N., The impacts of ventilation strategies and facade on indoor thermal environment for naturally ventilated residential buildings in Singapore. Building and Environment, 42, pp. 4006-4015, 2007.

[20] Brotas, L. \& Rusovan, D., Parametric Daylight Envelope. Proc. Of the 29th. Conf. on Sustainable Architecture for a Renewable Future, PLEA, Munich, Germany, 2013.

[21] Prianto, E. \& Depecker, P., Optimization of architectural design elements in tropical humid region with thermal comfort approach. Energy and Buildings, 35, pp. 273-280, 2003. 
[22] Kindangen, J.I., Window and roof configurations for comfort ventilation. Building Research and Information, 25(4), pp. 218-225, 1997.

[23] Prakash, K., Vijai, T. \& Kannan, R., Comprehensive Ventilation and Lighting Design of a Building as per SP-41 (Part 3 \& 4) using BIM. International Journal of Research in Civil Engineering, Architecture and Design, 1, pp. 28-38, 2013.

[24] Cammarano, S., Pellegrino, A., Lo Verso, V.R.M. \& Aghemo, C., Assessment of daylight in rooms with different architectural features. Building Research and Information, (ahead of print), 43(2), pp. 1-15, 2014.

[25] Lim, Y.W., Evaluation on sustainability and occupants' perceived health in Malaysian terraced houses. International Journal of Sustainable Building Technology and Urban Development, 5(2), pp. 128-134, 2014.

[26] Lim, Y.W., Building Modelling and Simulation for Green Building Design (Chapter 6). Sustainability in Built Environment, ed. Ahmad, M.H.: Johor, Malaysia, pp. 70-83, 2012.

[27] Zain-Ahmed, A., Sopian, K., Othman, M.Y., Sayigh, A.A. \& Surendran, P., Daylighting as a passive solar design strategy in tropical buildings: A case study of Malaysia. Energy Conversion and Management, 43, pp. 1725-1736, 2002.

[28] Chan, K.T. \& Chow, W.K., Energy impact of commercial-building envelopes in the sub-tropical climate. Appl. Energy, 60, pp. 21-39, 1998.

[29] Granadeiro, V., Correia, J.R., Leal, V.M.S. \& Duarte, J.P., Enveloperelated energy demand: A design indicator of energy performance for residential buildings in early design stages. Energy and Buildings, 61, pp. 215-223, 2013.

[30] Wang, L.S., Ma, P., Hu, E., Giza-Sisson, D., Mueller, G. \& Guo, N., A study of building envelope and thermal mass requirements for achieving thermal autonomy in an office building. Energy and Buildings, 78, pp. 79$88,2014$.

[31] Hamza, N., Dudek, S. \& Elkadi, H., Impacts of Changing Facades Configurations on Office Building Energy Consumption in Hot Arid Climates. Proc. Of the 7th. Rehva World Congress and Clima 2000, Naples, Italy, 2001.

[32] Olbina, S. \& Beliveau, Y., Decision-Making Framework for Selection and Design of Shading Devices Based on Daylighting. Journal of Green Building, 2(4), pp. 88-105, 2007.

[33] Capeluto, I.G., Energy performance of the self-shading building envelope. Energy and Buildings, 35, pp. 327-336, 2003.

[34] Lim, Y.W., Kandar, M.Z., Ahmad, M.H., Ossen, D.R. \& Abdullah, A. M., Building façade design for daylighting quality in typical government office building. Building and Environment, 57, pp. 194-204, 2012.

[35] Freewan, A.A., Shao, L. \& Riffat, S., Interactions between louvers and ceiling geometry for maximum daylighting performance. Renewable Energy, 34, pp. 223-232, 2009. 
[36] Kleindienst, S. \& Andersen, M., Comprehensive annual daylight design through a goal-based approach. Building Research and Information, 40, pp. 154-173, 2012.

[37] Laar, M. \& Grimme, F.W., German developments in guidance systems: An overview daylight. Building. Research and Information, 30, pp. 282301, 2002.

[38] Nazzal, A.A. \& Chutarat, A.A., New Daylight Glare Evaluation Method. Architectural Science Review, 44, pp. 71-82, 2001.

[39] Shen, H., Tzempelikos, A., Atzeri, A.M., Gasparella, A. \& Cappelletti, F., Dynamic Commercial Façades versus Traditional Construction: Energy Performance and Comparative Analysis. Journal of Energy Engineering, pp. 1-10, 2014.

[40] Sun, M., Ford, B. \& Lau, B., The Applicability of the Bio-Climatic Facade in a Hot and Humid Climate: A Study of Geoffrey Bawa's Architectural Works. Proc. Of the 29th. Conf. on Sustainable Architecture for a Renewable Future, PLEA, Munich, Germany, 2013.

[41] Zhu, J., Chew, D.A.S., Lv, S. \& Wu, W., Optimization method for building envelope design to minimize carbon emissions of building operational energy consumption using orthogonal experimental design (OED). Habitat International, 37, pp. 148-154, 2013.

[42] Ralegaonkar, R.V. \& Gupta, R., Review of intelligent building construction: A passive solar architecture approach. Renewable and Sustainable Energy Reviews, 14, pp. 2238-2242, 2010.

[43] Aminuddin, A.M.R., Rao, S.P. \& Thing, H.W., Thermal comfort field studies in two certified energy efficient office buildings in a tropical climate, International Journal of Sustainable Building Technology and Urban Development, 3, pp. 129-136, 2012.

[44] Ossen, D.R., Ahmad, M.H. \& Madros, N.H., Impact of Solar Shading Geometry on Building Energy Use in Hot Humid Climates with Special Reference to Malaysia. SUSTAINABLE SYMBIOSIS, National Seminar on Energy in Buildings (NSEB2005), UiTM, Subang Jaya, Malaysia, pp. 1020, 2005.

[45] Katz, D., Daylight Harvesting Technologies, Energy Engineering, 102(1), pp. 40-48, 2005.

[46] Mahdavinejad, M., Bemanian, M. \& Khaksar, N., Choosing Efficient Types of Smart Windows in Tropical Region Regarding to Their Advantages and Productivities. Proc. of International Conference on Intelligent Building and Management, IACSIT Press, Singapore, pp. 335$339,2011$.

[47] Iwaro, J. \& Mwasha, A., The impact of sustainable building envelope design on building sustainability using Integrated Performance Model. International Journal of Sustainable Built Environment, 2, pp. 153-171, 2013.

[48] Li, D.H.W. \& Lam, J.C., Solar heat gain factors and the implications to building designs in subtropical regions. Energy and Buildings, 32, pp. 4755,2000 . 
[49] Saidur, R., Hasanuzzaman, M., Hasan, M.M. \& Masjuki, H.H., Overall thermal transfer value of residential buildings in Malaysia. Journal of Applied Sciences, 9, pp. 2130-2136, 2009.

[50] Yu, J., Tian, L., Xu, X. \& Wang, J., Evaluation on energy and thermal performance for office building envelope in different climate zones of China. Energy and Buildings, 86, pp. 626-639, 2015.

[51] Sadineni, S.B., Madala, S. \& Boehm, R.F., Passive building energy savings: A review of building envelope components. Renewable and Sustainable Energy Reviews, 15, pp. 3617-3631, 2011.

[52] Laouadi, A., Atif, M.R. \& Galasiu, A., Methodology towards developing skylight design tools for thermal and energy performance of atriums in cold climates. Building and Environment, 38, pp. 117-127, 2003.

[53] Nour, M., Hosny, O. \& Elhakeem, A., A BIM-Based Approach For Configuring Buildings' Outer Envelope Energy Saving Elements. ITcon, 20, pp. 173-192, 2015.

[54] Stazi, F., Mastrucci, A. \& Munafò, P., Life cycle assessment approach for the optimization of sustainable building envelopes: An application on solar wall systems. Building and Environment, 58, pp. 278-288, 2012.

[55] Biswas, T. \& Wang, T., Framework for Sustainable Building Design. School of Architecture, 47, pp. 43-52, 2009.

[56] Hamza, N., Double versus single skin facades in hot arid areas. Energy and Buildings, 40, pp. 240-248, 2008.

[57] Kindangen, J., Krauss, G. \& Depecker, P., Effects of roof shapes on windinduced air motion inside buildings. Building and Environment, 32, pp. 1$11,1997$.

[58] Perén, J.I., van Hooff, T., Leite, B.C.C. \& Blocken, B., CFD analysis of cross-ventilation of a generic isolated building with asymmetric opening positions: Impact of roof angle and opening location. Building and Environment, 85, pp. 263-276, 2015.

[59] Teitel, M., Deriugin, M., Haslavsky, V. \& Tanny, J., Light distribution in multispan gutter-connected greenhouses: Effects of gutters and roof openings. Biosystems Engineering, 113, pp. 120-128, 2012.

[60] Henriques, G.C., Duarte, J.P. \& Leal, V., Strategies to control daylight in a responsive skylight system. Automation in Construction, 28, pp. 91-105, 2012.

[61] Tsangrassoulis, A. \& Santamouris, M., Method to estimate the daylight efficiency of round skylights. Energy and Buildings, 32, pp. 41-45, 2000.

[62] Sharples, S. \& Lash, D., Daylight in Atrium Buildings: A Critical Review. Architectural Science Review, 50, pp. 301-312, 2007.

[63] Al-Obaidi, K.M., Ismail, M. \& Abdul Rahman, A.M., A study of the impact of environmental loads that penetrate a passive skylight roofing system in Malaysian buildings. Frontiers of Architectural Research, 3, pp. 178-191, 2014.

[64] Klems, J., Net energy performance measurements on electrochromic skylights. Energy and Buildings, 33, pp. 93-102, 2001. 
542 Building Information Modelling (BIM) in Design, Construction and Operations

[65] To, D.W.T. \& Chan, T.K., Total Energy Performance of Atria with Daylight. HKIE Transactions, 13(2), pp. 24-30, 2006.

[66] Bedrick, J., Organizing the Development of a Building Information Model. The American Institute of Architects, AECbytes Feature, 2008.

[67] BIMForum 2013, Level of Development Specification. www.bimforum.org/lod

[68] Wood, J., Panuwatwanich, K. \& Doh, J.H., Using LOD in structural cost estimation during building design stage: Pilot study. Procedia Engineering, 85, pp. 543-552, 2014. 